\title{
Urticaria Due to Adverse Drug Reaction in Diabetes - A Case Presentation
}

\author{
Lata Kanyal Butolaํ, Ajay Meshram², Archana Dhok, Neelam Gusain4, Roshan Kumar Jha ${ }^{5}$
}

\begin{abstract}
${ }^{1}$ Department of Biochemistry, Jawaharlal Nehru Medical College, Sawangi Wardha, Maharashtra, India. ${ }^{2}$ Department of Biochemistry, Jawaharlal Nehru Medical College, Sawangi Wardha, Maharashtra, India. ${ }^{3}$ Department of Biochemistry, Jawaharlal Nehru Medical College, Sawangi Wardha, Maharashtra, India. ${ }^{4}$ Department of Biochemistry, Al Falah School of Medical Science and Research, Haryana, India. ${ }^{5}$ Department of Biochemistry, Jawaharlal Nehru Medical College, Sawangi Wardha, Maharashtra, India.
\end{abstract}

\section{INTRODUCTION}

Type 2 diabetes mellitus (T2DM) is a chronic condition caused by the inability of pancreas to produce enough insulin. Insulin lowers the blood glucose and enables it to enter the cells. Urticaria also known as hives is a result of skin reaction when certain body cells release histamine. They are itchy and can appear in any part of the body. Metformin is the first line of treatment for type 2 diabetes mellitus for controlling high blood sugar by decreasing glucose production by the liver and by increasing insulin sensitivity of body tissues. India is at the top of the world with highest number of people with diabetes mellitus (31.7 million). WHO has predicted that by 2030 T2DM may affect up to 79.4 million individuals in India. ${ }^{1}$

Diabetes mellitus is a group of metabolic disorder characterized by increased glucose production and decreased glucose utilization and the complications arising from this disease are major causes of death worldwide. Cells of the body cannot metabolize carbohydrate due to relative or complete lack of insulin, and so the body breaks its own protein, fat and glycogen resulting in hyperglycemia. ${ }^{2,3} \mathrm{~T} 2 \mathrm{DM}$ earlier referred to as non-insulin dependent diabetes or adult onset diabetes, accounts for $90-95 \%$ of all diabetes. ${ }^{4}$ Metformin is an oral agent and is considered as insulin sensitizer because it helps in lowering insulin levels, reduces hepatic glucose production, improves peripheral glucose utilization, and helps in uptake and utilization of gut glucose. ${ }^{5}$

Urticaria is caused by dermal oedema, secondary to temporary increase in capillary permeability resulting from increased release of histamine from the mast cells situated around the capillaries. Urticaria present for more than 6 weeks is considered to be acute and chronic. ${ }^{6}$

\section{Types of Urticaria 7}

- Spontaneous Urticaria

- Acute Urticaria

- Intermittent (episodic) Urticaria

- Chronic Urticaria

\section{Causes of Urticaria ${ }^{2}$}

- Autoimmune due to antibodies that cross link the IgE receptor on mast cells

- Allergens in foods and inhalants

- Contact allergens, latex, animal saliva

- Drugs

- $\quad$ Physical stimuli, heat, cold, pressure, sun, sweat, water

- $\quad$ SLE, pregnancy, thyroid disease
Corresponding Author:

Lata Kanyal Butola,

Tutor, Department of Biochemistry, Jawaharlal Nehru Medical College, Sawangi Wardha, Maharashtra, India E-mail: kanyallata1010@gmail.com

DOI: $10.14260 / \mathrm{jemds} / 2020 / 600$

How to Cite This Article:

Butola LK, Meshram A, Dhok A, et al. Urticaria due to adverse drug reaction in diabetes: a case presentation. $J$ Evolution Med Dent Sci 2020;9(37):2764-2766, DOI: 10.14260/jemds/2020/600

Submission 14-05-2020,

Peer Review 04-08-2020,

Acceptance 10-08-2020,

Published 14-09-2020.

Copyright (C) 2020 JEMDS. This is an open access article distributed under Creative Commons Attribution License [Attribution 4.0 International (CC BY 4.0)] 


\section{PRESENTATION OF CASE}

A 26-year-old woman visited the physician complaining of itching from past 2 weeks. The patient was recently diagnosed with type 2 diabetes mellitus during a routine check-up. The reported blood sugar at that time was $276 \mathrm{mg} / \mathrm{dl}$ and an HbA1c of $7.6 \%$. The patient was earlier diagnosed with PCOD, Hypothyroidism and obesity. The physician had prescribed metformin $500 \mathrm{mg}$ (BD). After taking metformin for 20 days, the patient initially develops itchy red colour spots on her hand which was developed later in the whole body. Patient was advised to stop metformin and take sitagliptin phosphate $100 \mathrm{mg}$ (OD). Physician recommended routine biochemistry investigation which revealed slightly decreased serum creatinine $(0.5 \mathrm{mg} / \mathrm{dl})$ and Vitamin C $(0.26 \mathrm{mg} / \mathrm{dl})$ levels with an increase in SGOT (47 U/L) and SGPT (51 U/L). Patient was consulted to a dermatologist and oral histamine (cetirizine 10 $\mathrm{mg}$ ) was started, however rashes did not show any changes and infact gradually increased. Then the patient was prescribed with tab Levosiz M $10 \mathrm{mg}$ (BD) and lotion Dermocalm (BD), and the rashes finally disappeared after 2 days.

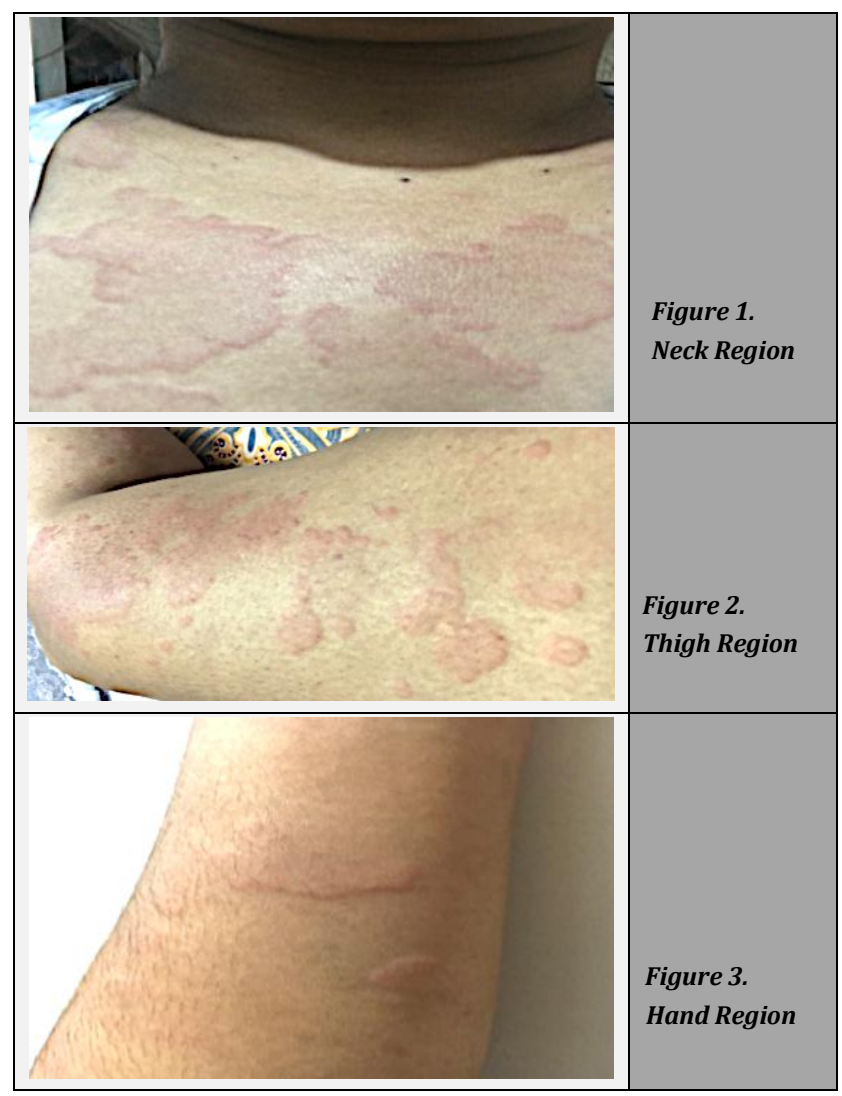

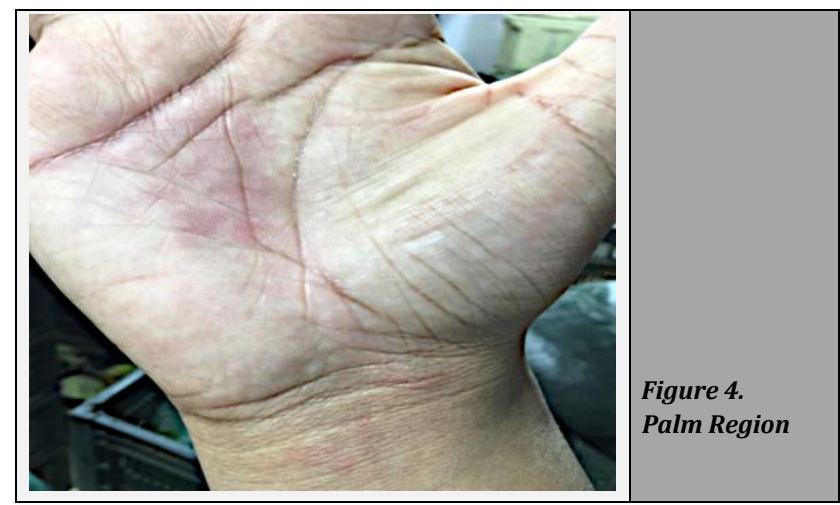

A weal is a descriptive term for transient, well-demarcated, superficial pink or pale swelling of the dermis due to reversible exudation of plasma in the skin that fade, usually within hours, without leaving a mark. The weals are usually very itchy and associated with a surrounding red flare when they arise.

\section{DISCUSSION}

Increasing number of diabetes patients is a prominent health problem worldwide. Metformin is the first line drug used in treating diabetes. In this study, the author reported a case of drug induced urticaria with itching nearly 1 month after initiation of metformin. Several studies show that metformin leads to low TSH levels in patients with treated hypothyroidism, also the underactive thyroid raise the risk of type 2 diabetes mellitus and slows down the metabolism, which leads to weight gain.

Hives causes itching and appears anywhere in the body. They are as small as an eraser or as large as a dinner plate joining together to form larger areas known as plaques. The most common cause of urticaria is allergy to medications, food, stress, etc. So antihistamines should be given to get relief from symptoms.

\section{CONCLUSIONS}

In the present case, the skin eruption is induced by an allergic reaction to metformin. Close attention should be paid to patients receiving oral hypoglycaemic drug and initially a low dose should be given to the patient with proper diet and exercise to minimize the itchy skin eruptions.

A written and informed consent form was obtained from the patient for publication of the case and accompanying images.

Financial or other competing interests: None.

\section{REFERENCES}

[1] Badyal A, Kumar S. Role of Vitamin B12 deficiency in patients with type 2 diabetes mellitus. J Med Sci Clin Res 2018;6(2):235-8.

[2] Longo DL, Fauci AS, Kasper DL, et al. eds. Harrison's Principles of internal medicine. 19th edn. McGraw-Hill Medical 2014. 
[3] Agarwal P, Mital P, Meena VK, et al. A comparative study of levels of vitamin B12 in patients of type 2 diabetes mellitus on metformin and not on metformin at tertiary care center. Inter J Advan Med 2016;3(3):759-63.

[4] American Diabetes Association. 2. Classification and diagnosis of diabetes. Diabetes Care 2017;40(Suppl 1):S11-S24.
[5] Ralston SH, Penman ID, Strachan MWJ, et al. Davidson's Principles and practice of medicine. $23^{\text {rd }}$ edn. Elsevier 2018.

[6] James WD, Berger TG, Elston DM, et al. Andrew's Diseases of the skin: clinical dermatology. 12 $2^{\text {th }}$ edn. Elsevier 2015.

[7] Griffiths C, Barker J, Bleiker T, et al. Rook's Textbook of

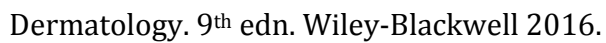

